Mirek Agnieszka ${ }^{1,2}$, Ruta Karolina ${ }^{1,2}$, Suchmiel Mateusz ${ }^{1,2}$, Gajda Mateusz ${ }^{1,2}$,

† Klimek-Piotrowska Wiesława, , Talaga-Ćwiertnia Katarzyna ${ }^{4}$.

\title{
ASSESSMENT OF ACCESS TO SOCIAL AND MEDICAL HELP FOR HOMELESS PEOPLE IN CRACOW IN THE CONTEXT OF HEALTH PROBLEMS
}

\author{
OCENA DOSTĘPU DO POMOCY SOCJALNEJ I MEDYCZNEJ DLA OSÓB \\ BEZDOMNYCH W KRAKOWIE W KONTEKŚCIE PROBLEMÓW ZDROWOTNYCH
}

\author{
${ }^{1}$ Scientific Group of Humanitarian Medicine, Jagiellonian University Medical College, Cracow, Poland \\ ${ }^{2}$ Foundation "Przystań Medyczna", Cracow, Poland \\ ${ }^{3}$ Department of Anatomy, Jagiellonian University Medical College, Cracow, Poland \\ ${ }^{4}$ Department of Mycology, Chair of Microbiology, Faculty of Medicine, \\ Jagiellonian University Medical College, Cracow, Poland \\ ${ }^{1}$ Studenckie Koło Naukowe Medycyny Humanitarnej, Uniwersytet Jagielloński Collegium Medicum, Kraków, Polska \\ ${ }^{2}$ Fundacja Przystań Medyczna, Kraków, Polska \\ ${ }^{3}$ Zakład Anatomii, Wydział Lekarski, Uniwersytet Jagielloński Collegium Medicum, Kraków, Polska \\ ${ }^{4}$ Zakład Mykologii, Katedra Mikrobiologii, Wydział Lekarski, Uniwersytet Jagielloński Collegium Medicum, \\ Kraków, Polska
}

\begin{abstract}
INTRODUCTION. Although homelessness is a worldwide problem also present in Poland and the Małopolska region, the data about it are not sufficient.

AIM OF THE STUDY. Assessment of the general situation in Cracow and help options for homeless people. MATERIALS AND METHODS. A survey study conducted in 11 places offering refuge to homeless people in Cracow. RESULTS. In Cracow, there were 691 places to sleep in 11 institutions. Nine out of 11 were open all year long and most of them were available only for men. Five institutions offered meals, all of them had bathrooms, 7 places provided medical help.

DISCUSSION. The expected number of homeless people in Poland and in Cracow seems to be underestimated. Basic needs of homeless people remain unsatisfied which decreases the possibility of transitioning out of homelessness.

CONCLUSIONS. Help available for homeless people in Cracow needs improvements in all of the areas examined.
\end{abstract}

Key words: homeless people, hygiene, medical help, social help

\section{STRESZCZENIE}

WSTĘP. Mimo iż bezdomność jest problemem ogólnoświatowym występującym również w Polsce i regionie małopolskim, dane na jej temat nie są wystarczające.

CEL PRACY. Ocena sytuacji osób bezdomnych w Krakowie i dostępnej dla nich pomocy.

MATERIALY I METODY. Ankieta przeprowadzona w 11 miejscach oferujących schronienie dla osób bezdomnych na terenie Krakowa.

WYNIKI. Na terenie Krakowa znajduje się 691 miejsc noclegowych w 11 instytucjach. Dziewięć z 11 jest otwartych całorocznie, większość dostępna jest tylko dla mężczyzn. Pięć placówek oferowało posiłki, wszystkie instytucje posiadały łazienki, w 7 miejscach zapewniano opiekę medyczną.

DYSKUSJA. Szacowana liczba osób bezdomnych w Polsce i Krakowie wydaje się być zaniżona. Podstawowe potrzeby ludzi bezdomnych pozostają niezaspokojone, co obniża ich szanse na wyjście z bezdomności.

WNIOSKI. Pomoc oferowana ludziom bezdomnym w Krakowie wymaga rozwinięcia we wszystkich wymiarach.

Slowa kluczowe: osoby bezdomne, higiena, świadczenia medyczne, pomoc socjalna

\section{INTRODUCTION}

Homeless people are a poorly defined social group because there is a lack of a universal definition of
WSTĘP

Osoby bezdomne to nieprecyzyjnie określona grupa społeczna, ponieważ nie istnieje uniwersalna definicja 
homelessness. In the United Kingdom, the Housing Act of 1996 states that "a person is homeless if there is no accommodation that they are entitled to occupy or they have accommodation, but it is not reasonable for them to continue to occupy this accommodation".

The European Typology of Homelessness and Housing Exclusion (ETHOS) defines a person as homeless if "they have a deficit in at least two of the physical, legal and social domains - also described as being roofless or houseless". Whereas in Australia, homelessness is defined as "primary (without regular accommodation), secondary (living in shelters or temporarily with family or friends or boarding homes), or tertiary (living in substandard housing, e.g., boarding homes)" $(1,2)$. In Poland, a homeless person is defined as somebody "not living in a residential unit, as defined in provisions on the protection of tenants' rights and the housing resources of the commune, not registered for permanent residence as defined in regulations on population records, as well as a person that does not live in a dwelling or is registered for permanent residence in a place where there is no possibility of residence" (3). The lack of a clear definition is a great challenge when attempting to determine the number of homeless people in a given region or country. The level of homelessness in Poland was determined when a count was conducted at night from 8 to 9 February 2017. Information was collected from shelters, warming centers, hospitals, jails, etc., and in non-residential areas such as railway stations, basements, gardens, and streets (4). Generally, the number of homeless people in Poland decreased from 36,160 to 33,410 people between 2015 and 2017.

However, in the Małopolska region, in the same period, the number of the homeless increased by 112 people, from 1,942 to 2,054 people. Despite these changes, homelessness is still a significant problem in our country (4). The detailed data are presented in Figure 1.

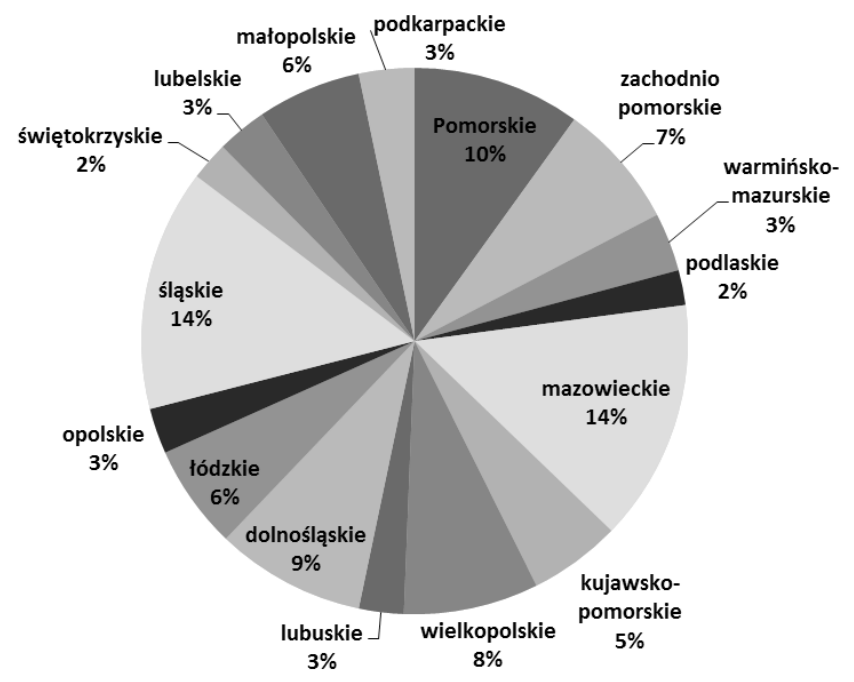

Fig. 1. The number of the homeless in Poland, by region, in 2017 (4).

Ryc. 1. Liczba osób bezdomnych w Polsce w 2017 roku z podziałem na województwa (4). bezdomności. W Wielkiej Brytanii „Housing Act” z 1996 roku głosi, że „osoba jest bezdomna, jeżeli nie ma miejsca zakwaterowania, do którego ma prawo wprowadzić się lub ma zakwaterowanie, ale nie jest racjonalne, aby nadal zajmowała to miejsce". Europejska Typologia Bezdomności i Wykluczenia Mieszkaniowego (ang. European Typology of Homelessness and Housing Exclusion, ETHOS) definiuje osobę, jako bezdomną, jeśli „ma deficyt w co najmniej dwóch domenach fizycznych, prawnych i społecznych - również określanych jako pozbawione dachu lub bezdomne". Natomiast w Australii bezdomność jest określana, jako ,pierwotna (bez regularnego zakwaterowania), wtórna (mieszkanie w schronisku lub tymczasowo $\mathrm{z}$ rodziną lub przyjaciółmi lub w pensjonacie) lub trzeciorzędowa (mieszkanie w niestandardowych mieszkaniach, np. w domach z internatem)" (1,2). W Polsce bezdomny to „osoba niezamieszkująca w lokalu mieszkalnym w rozumieniu przepisów o ochronie praw lokatorów i mieszkaniowym zasobie gminy i niezameldowana na pobyt stały, w rozumieniu przepisów o ewidencji ludności, a także osoba niezamieszkująca $w$ lokalu mieszkalnym i zameldowana na pobyt stały w lokalu, w którym nie ma możliwości zamieszkania" (3). Brak jasnej definicji stanowi wielkie wyzwanie przy próbie ustalenia liczby osób bezdomnych w danym regionie lub kraju.

Liczba osób bezdomnych w Polsce została podana na podstawie zliczania, które miało miejsce w nocy z 8 na 9 lutego 2017 roku. Informacje zbierano w schroniskach, ogrzewalniach, szpitalach, więzieniach itd., oraz na innych terenach, takich jak stacje kolejowe, piwnice, ogródki działkowe, ulice (4). Ogólnie w Polsce, liczba osób bezdomnych spadła pomiędzy rokiem 2015 a 2017, z 36160 do 33410 osób. Natomiast w województwie małopolskim, w tym samym okresie, liczba ta wzrosła o 112 osób z 1942 osób do 2054 osób. Pomimo zachodzących zmian, bezdomność nadal stanowi duży problem w naszym kraju (4). Szczegółowe dane przedstawiono na Rycinie 1 .

Kraków jest drugim miastem pod względem liczby mieszkańców, natomiast czwartym pod względem liczby osób bezdomnych w naszym kraju (4). O ile liczba osób bezdomnych jest możliwa do oszacowania lub policzenia, to niewiele jest źródeł informujących o dostępie do pomocy socjalnej i medycznej w zależności od kraju zamieszkania. Również w Polsce te dane są skąpe i niedoprecyzowane.

\section{CEL PRACY}

Celem niniejszej pracy było zgromadzenie informacji dotyczących osób bezdomnych w Krakowie, pomocy, którą mogą uzyskać, szczególnie miejsc do spania, pomocy medycznej, posiłków i dostępu do sanitariatów.

\section{MATERIAŁY I METODY}

W badaniu wykorzystaliśmy metodę sondażu diagnostycznego oraz technikę ankiety. Jako narzędzie 
Cracow is a city that takes second place in terms of the number of residents in Poland, while it is fourth as regards the number of homeless people [4].

Although it is possible to estimate or count the number of homeless people, there are few sources of information about access to social and medical assistance, depending on the country of residence. Also in Poland, these data are insufficient and imprecise.

\section{AIM OF THE STUDY}

The aim of this study was to collect the data about homeless people in Cracow, the help that they can get, particularly about places to stay, medical help, meals, and access to sanitary facilities.

\section{MATERIALS AND METHODS}

In the study, we used the diagnostic survey method. As a research tool, we applied an our own questionnaire containing 14 original questions divided into four categories: accommodation, meals, medical help and hygiene (Table I). We conducted surveys with people managing 11 institutions which offer refuge for homeless people in Cracow from 1st November 2017 to 25th April 2018. These institutions are financed or supported by the Municipal Social Welfare Centre.

\section{RESULTS}

In 2017-2018, in centers offering refuge for the homeless in Cracow, there were 691 places to sleep, from which 596 were beds, 70 were mattresses and 25 were places to sit. Two places gave only overnight shelter and the homeless had to leave obligatorily during the day. In our survey, 8 out of 11 institutions were homeless shelters, and the next 3 were a warming center, a care facility, and an intervention institution, respectively. The other places were open seasonally: the center for people affected by violence only from 1st November to 1st March, and the warming center from August to June. Most of the institutions were available only for men $(54.5 \%)$. Three were dedicated to women only (27.2\%) and two were mixed-sex (18.2\%). Only two places admitted the homeless under the influence of alcohol. One of them was available only in winter and permitted only $2 \%$ of alcohol in the exhaled air. Five (45.5\%) places offered meals, but one of them served them only for 50 people who were staying there. There were 49 showers in 10 places (there were no data on the number of showers from one of the places) with hygienic products in all of them. In ten out of eleven institutions, there was a possibility to take a shower every day. The data that we obtained during the study from 11 institutions are presented in detail in Table I. badawcze zastosowaliśmy autorski kwestionariusz ankiety, który zawierał 14 pytań autorskich podzielonych na cztery kategorie: nocleg, wyżywienie, opieka medyczna, higiena (Tabela I). Sondaż przeprowadziliśmy pomiędzy 1 listopada 2017 a 25 kwietnia 2018 z osobami zarządzającymi 11 miejscami oferującymi schronienie dla osób bezdomnych w Krakowie. Ankietowane placówki są finansowane lub wspierane przez Miejski Ośrodek Pomocy Społecznej (MOPS).

\section{WYNIKI}

W latach 2017-2018 w ośrodkach oferujących schronienie bezdomnym w Krakowie było 691 miejsc noclegowych, w tym 596 łóżek, 70 materacy oraz 25 miejsc do siedzenia. Dwa ośrodki udzielały schronienia tylko w nocy, z obowiązkiem opuszczenia schroniska w ciągu dnia. W naszym badaniu osiem z 11 instytucji było schroniskami dla bezdomnych, a kolejne trzy to odpowiednio: ogrzewalnia, placówka opiekuńcza oraz instytucja interwencyjna. Dziewięć z ankietowych instytucji $(81,8 \%)$ prowadziło działalność przez cały rok, dwie pozostałe działały sezonowo: ośrodek dla osób dotkniętych przemocą tylko od 1 listopada do 1 marca, a ogrzewalnia od sierpnia do czerwca. W większości placówek przebywać mogli jedynie mężczyźni $(54,5 \%)$. Trzy instytucje przyjmowały wyłącznie kobiety $(27,2 \%)$ a dwie były koedukacyjne $(18,2 \%)$. Jedynie w dwóch miejscach przyjmowano bezdomnych pod wpływem alkoholu, z zastrzeżeniem, że jedno z tych miejsc było dostępne tylko zimą i przyjmowało bezdomnych, jeśli poziom alkoholu w wydychanym powietrzu wynosił poniżej $2 \%$. W pięciu ankietowanych miejscach $(45,5 \%)$ zapewniano wyżywienie, natomiast $\mathrm{w}$ jednym posiłki przewidziane były jedynie dla 50 osób przebywających na terenie ośrodka. W 10 instytucjach (nie uzyskano danych na temat jednego ośrodka) znajdowało się 49 pryszniców z dostępem do wszystkich przyborów higienicznych. W dziesięciu z 11 miejsc z prysznica można było skorzystać codziennie. Dane, które uzyskaliśmy podczas badania z 11 instytucji, przedstawiono szczegółowo w Tabeli I.

Wśród 11 ankietowanych instytucji, siedem $(63,6 \%)$ zapewniało pomoc medyczną, jednak jedynie w 4 miejscach $(36,4 \%)$ była ona świadczona przez lekarzy. Wyłącznie w jednej placówce lekarz był zatrudniony w ramach etatu i przyjmował chorych codziennie, w dwóch lekarze dyżurowali w ramach wolontariatu dwa razy $\mathrm{w}$ tygodniu w wyznaczonych godzinach. W ostatnim ośrodku opiekę medyczną zapewniał lekarz współprowadzący placówkę jedynie dla bezdomnych ubezpieczonych. W pozostałych instytucjach, w których świadczono pomoc medyczną, była ona udzielana przez pielęgniarki ( $\mathrm{n}=2 ; 18,2 \%)$ lub przez wyszkolony personel $(\mathrm{n}=1 ; 9,1 \%)$ i była to pomoc doraźna, w większości przypadków ograniczając się do zmiany opatrunków. 


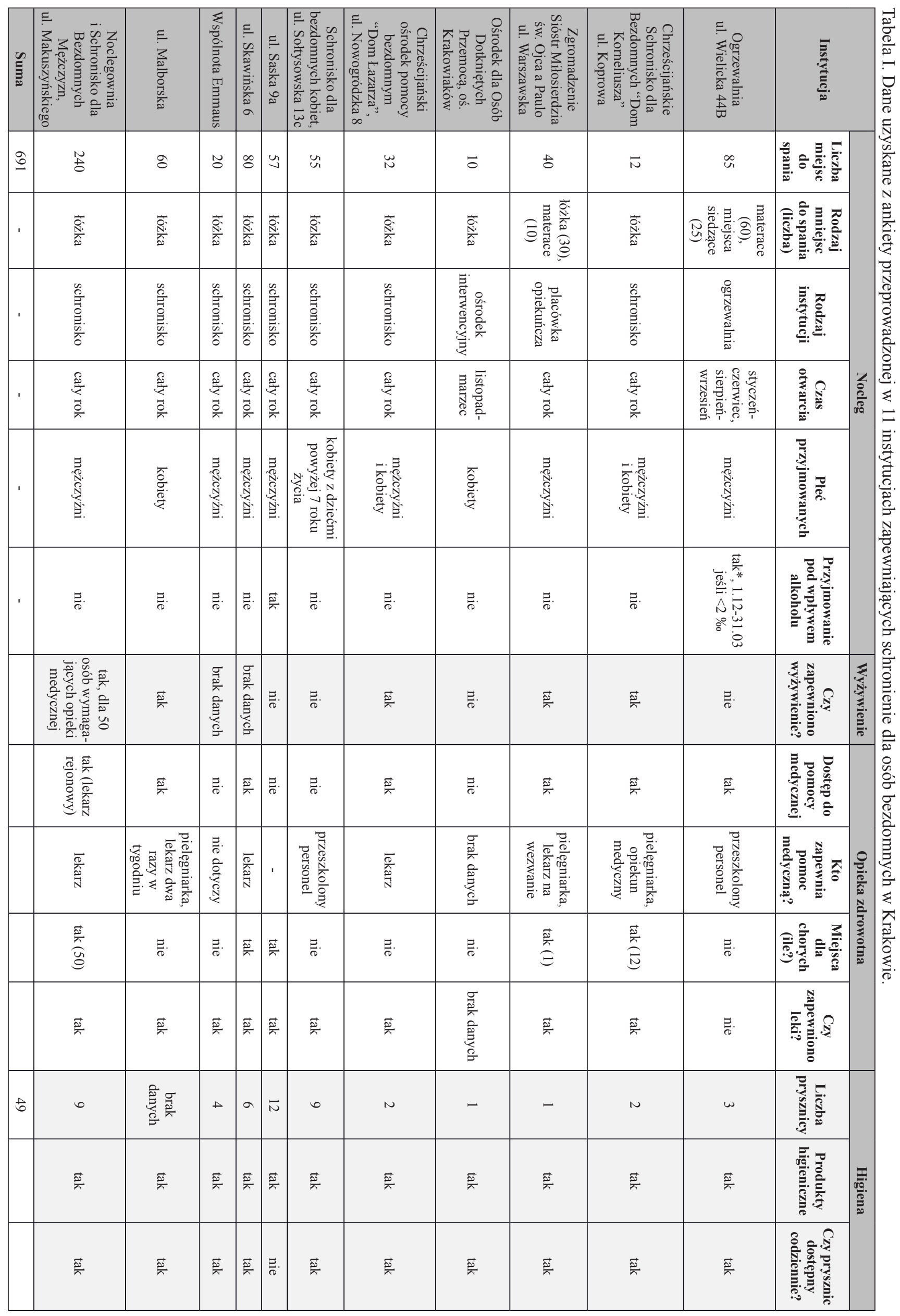




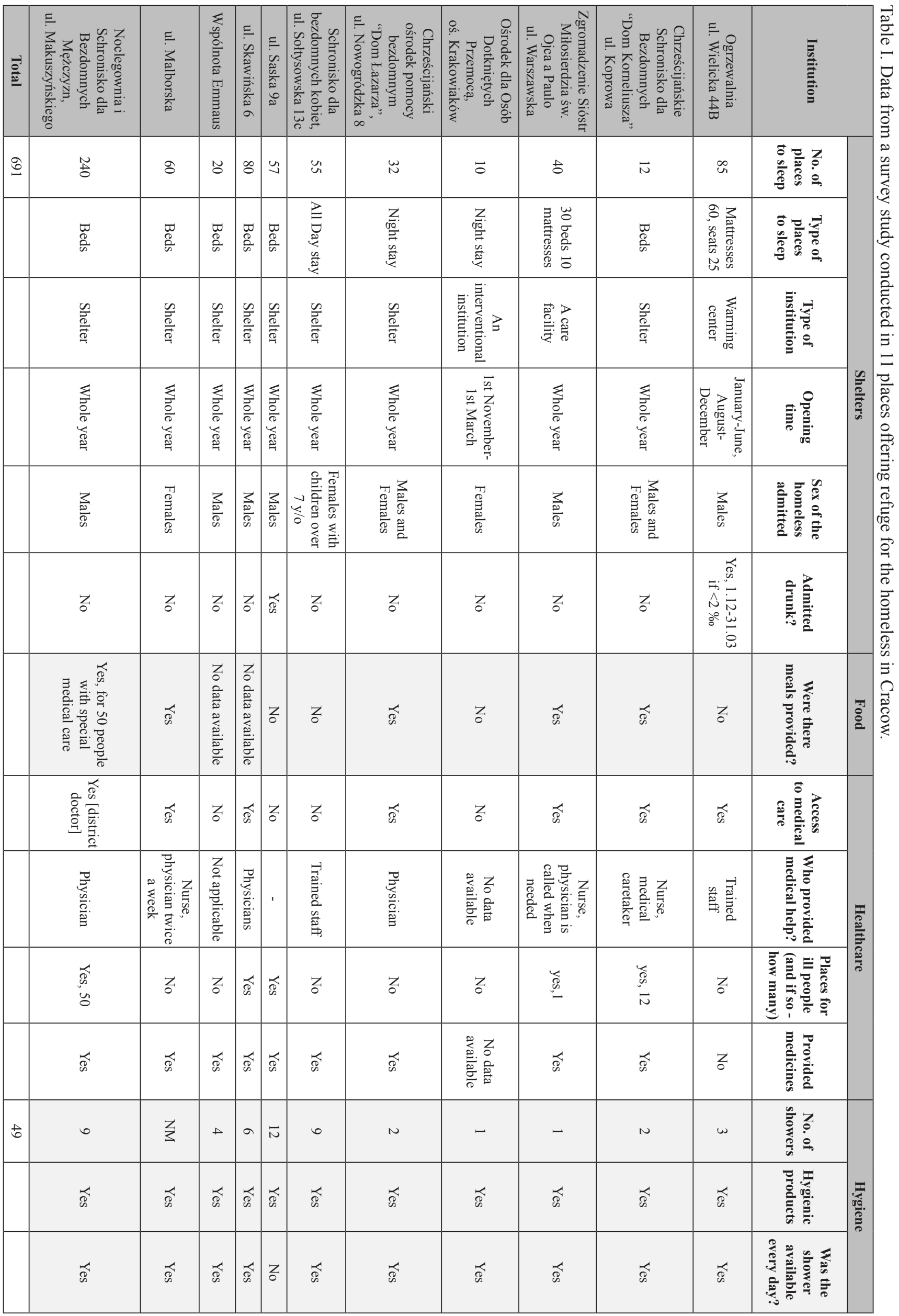


7 out of 11 institutions $(63.6 \%)$ were providing medical help but only in 4 cases $(36.4 \%)$ it was provided by physicians. In 1 institution, a medical doctor was employed on a full-time basis, the doctor was available every day, in two places medical doctors were volunteering twice a week during designated hours. In the last one, doctor's help was available only for homeless individuals with health insurance. In the remaining institutions, medical help was provided by nurses $(n=2,18.2 \%)$ or by trained personnel $(n=1$, 9.1\%) and was available when needed, but in most cases, it was changing dressings. Nine out of eleven institutions were providing the most commonly used medicines including antibiotics and antipyretic medicines. Detailed availability of medical help is presented in Figure 2.
Dziewięć z 11 placówek zapewniało najczęściej stosowane leki, w tym antybiotyki i leki przeciw gorączkowe. Szczegółowo zapewnienie pomocy medycznej przedstawiono na Rycinie 2.

Wśród ankietowanych instytucji tylko dwie posiadały specjalne miejsca wydzielone dla osób chorych (łącznie 62 miejsca). W Chrześcijańskim Schronisku dla Bezdomnych „Dom Korneliusza” oraz w Noclegowni i Schronisku dla Bezdomnych Mężczyzn na ul. Makuszyńskiego dla chorych osób były przygotowane osobne pomieszczenia, w tym, w drugim wyznaczone było całe piętro. Natomiast w pozostałych placówkach, które przyjmowały chorych, nie przeznaczono dla nich oddzielnych miejsc i chorzy mogli w nich przebywać pod warunkiem ,samoobsługi”.

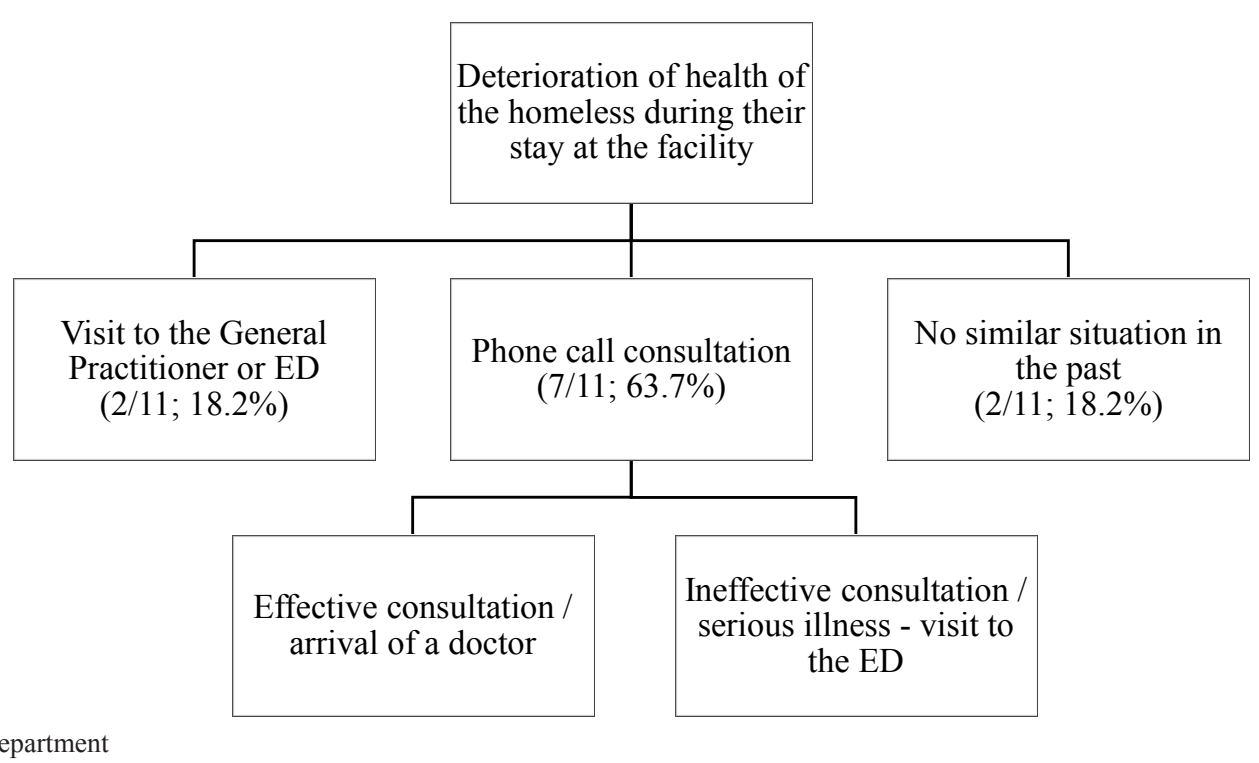

ED - Emergency Department

Fig. 2. An algorithm presenting the procedures in the situation of health deterioration of a homeless person in the institutions helping homeless people in Cracow.

Ryc. 2. Algorytm przedstawiający postępowanie w sytuacji pogorszenia stanu zdrowia osoby bezdomnej w różnych schroniskach w Krakowie.

Only two institutions had special places for patients (a total of 62 places). At the Chrześcijańskie Schronisko dla Bezdomnych "Dom Korneliusza" and the Noclegownia i Schronisko dla Bezdomnych Mężczyzn on Makuszyński Street had separate rooms for ill people, including the fact that, in the second institution, a whole floor was offered. However, other facilities that admitted ill people had no separate places for them and the patients could stay at those places under the condition of "self-service".

\section{DISCUSSION}

From our experience, as people working with the homeless (streetworkers), it appears that collecting information about the number of homeless people is very difficult because of their constant migration and unknown places of residence. All these factors cause

\section{DYSKUSJA}

Z naszych doświadczeń, jako osób pracujących z bezdomnymi (,streetworkerów”) wynika, że zbieranie informacji o liczbie osób bezdomnych jest bardzo trudne, ze względu na ciągłą migrację osób bezdomnych oraz nieznane lokalizacje ich pobytu. Wszystkie te czynniki powodują, że raport Ministerstwa Pracy i Polityki Społecznej (MPiPS) (5), o którym mowa we wstępie niniejszej pracy, nie jest spójny z sytuacją, jaką można zaobserwować w naszym kraju. Jednakże taka metoda zliczania jest używana powszechnie, co może stanowić wythumaczenie zaniżonej liczby osób bezdomnych na świecie (6), a także w Polsce. Wiarygodna ocena liczby bezdomnych pozwoliłaby oszacować zapotrzebowanie na liczbę miejsc dla bezdomnych w Krakowie. $\mathrm{Z}$ porównania danych uzyskanych przez nas $\mathrm{w}$ trakcie sondażu w placówkach pomagających osobom bez- 
the report from the Ministry of Labour and Social Policy (5), mentioned in the introduction to this study, not to be consistent with the situation observed in our country. However, this method of calculation is used worldwide, which can be an explanation for the underestimation of the number of homeless people in the whole world (6) and in Poland. Reliable estimation of the number of the homeless would allow assessing the need for new facilities for the homeless in Cracow. Comparing data from the questionnaire in places offering refuge for the homeless and data about their numbers in Cracow in 2015, the basic need for places to sleep was not covered (691 places and 1,050 homeless people) (4). Moreover, some of the places are not open all year round (Table I), which periodically reduces the availability of accommodation for the homeless. We cannot forget that homeless people form a kind of micro-community in which there are also couples. As volunteers of the "Przystań Medyczna" foundation, we received information that these couples prefer to stay outside than to have a possibility to sleep in the shelter separately. For these reasons, homeless people are forced to sleep on benches in parks, under bridges or on train platforms. It is a serious problem especially during late autumn and in winter when the temperature is below $0^{\circ} \mathrm{C}$, which poses a threat to their health and lives. Romaszko et al. point out that the problem is growing with the number of people drinking alcohol (78.5\% in Poland), making them sensitive to hypothermia (7). Unfortunately, it is often caused by addiction maintained due to the fear of the effects of withdrawal. In Cracow, it is important considering the fact that simultaneous accommodation for men and women is available only in two places. \%o). In Poland, the number of deaths caused by hypothermia in the autumn/winter period was oscillating between 62 to 178 from 2012 to 2018 (8). This amount of deaths may suggest that the city council in Cracow should organize more facilities where the homeless can find refuge from low temperatures and also consider preparing shelters for people who are intoxicated.

Although the interviewed institutions offering help for the homeless in Cracow are financed entirely or partially by the Municipal Social Welfare Centre and it would be expected that it allows coordination, the information flow about the available places and the possibility of redirecting homeless people in case of overcrowding, as a matter of fact, does not exist. Lack of coordination may contribute to improper diagnosis or underestimation of the needs of the homeless. Hope for improvement of homeless status in Poland and in Cracow is the introduction of the Charter of Homeless Rights. The document is now in the project phase. It was prepared by the European Federation of National Organisations Working with the Homeless domnym oraz z danych o liczbie bezdomnych w roku 2015 w Krakowie nie pokryto zapotrzebowania na miejsca noclegowe (691 miejsc i 1050 osób bezdomnych) (4). Co więcej, niektóre z placówek nie są czynne przez cały rok (Tabela I), co okresowo zmniejsza dostępność miejsc noclegowych dla bezdomnych. Nie można także zapominać, że bezdomni tworzą rodzaj „mikrośrodowiska", w którym łączą się również w pary. Jako wolontariusze Fundacji „Przystań Medyczna” uzyskaliśmy informacje, że te pary wolą pozostać na zewnątrz, niż osobno mieć możliwość nocowania w schroniskach. $\mathrm{Z}$ tych powodów osoby bezdomne zmuszone są spać na lawkach w parkach, pod mostami lub na peronach. Jest to poważny problem, szczególnie występujący późną jesienią i zimą, gdy temperatura spada poniżej $0^{\circ} \mathrm{C}$, co stanowi zagrożenie dla ich zdrowia i życia. Romaszko $i$ wsp. wskazują, iż problem z otrzymaniem noclegu rośnie wraz z liczbą osób pijących alkohol (78,5\% w Polsce), co czyni je wrażliwymi na hipotermię (7). Niestety, często jest to spowodowane uzależnieniem utrzymywanym przez strach przed skutkami wycofania. W Krakowie ten aspekt jest istotny ze względu na możliwość równoczesnego nocowania kobiet i mężczyzn tylko w dwóch placówkach. W Polsce liczba zgonów z powodu hipotermii w okresie jesienno-zimowym mieściła się w granicach od 62 do 178 w latach od 2012-2018 (8). Ta liczba zgonów może sugerować, że władze miasta Krakowa powinny zorganizować więcej miejsc, w których bezdomni mogą znaleźć schronienie przed niskimi temperaturami, a także rozważyć przygotowanie schronień dla osób odurzonych.

Mimo, iż ankietowane instytucje udzielające pomocy osobom bezdomnym w Krakowie są finansowane w całości lub częściowo przez MOPS i można by oczekiwać, że ten fakt umożliwia koordynację, to przepływ informacji w zakresie posiadania wolnych miejsc i możliwości przekierowania bezdomnych w wypadku przepełnienia właściwie nie istnieje. Brak koordynacji może przyczyniać się do niewłaściwego zdiagnozowania lub niedoszacowania potrzeb bezdomnych również w innych aspektach. Nadzieją na polepszenie statusu osób bezdomnych w Polsce, w tym również w Krakowie, jest wprowadzenie Karty Praw Bezdomnych. Obecnie dokument znajduje się w fazie projektu. Został on przygotowany przez Europejską Federację Organizacji Narodowych Pracujących z Bezdomnymi (FEANTSA) oraz przez „Housing Rights Watch”. Zawiera zobowiązania władz publicznych w stosunku do podstawowych praw osób dotkniętych bezdomnością. Komisja Przeciwdziałania Bezdomności ma również na uwadze potrzebę dostosowania założeń Karty do warunków polskich (9).

$\mathrm{Z}$ naszego badania wynika, że tylko $5 \mathrm{z} 11 \mathrm{kra}-$ kowskich schronisk $(45,5 \%)$ zapewniało posiłki dla bezdomnych, a w większości z pozostałych osoby 
(FEANTSA) and Housing Rights Watch. It includes commitments by public authorities to the basic rights of people affected by homelessness. The Commission for Counteracting Homelessness also has in mind the need to adapt the Card's assumptions to the Polish conditions (9).

From our study, it appears that only 5 of 11 shelters in Cracow (45.5\%) provided meals for the homeless and, in most of the remaining ones, homeless people had the opportunity to prepare food by themselves. According to the data from the Municipal Social Welfare Centre, in 2016 in Cracow, there were 7 kitchens preparing hot meals for the homeless, the poor and the elderly. Altogether, the institutions were issuing about 1,350 meals daily. In 2016, the number of meals provided amounted to 328,443 and was similar in the years 2013-2015. The number of people receiving these meals in the years 2013-2015 was around 4,000 each year (4). According to these data, the number of meals issued exceeds the estimated number of homeless individuals in Cracow. Moreover, the number of people receiving free meals $(4,344)$ is higher than the estimated number of the homeless in Cracow, which suggests that poor and older, nonhomeless people are also using this form of help (4). Taking all these data into account, the availability and quantity of meals for the homeless population in Cracow seem to be satisfactory. However, it is difficult to clearly evaluate the obtained data. First of all, there is no access to any information about the methods used to count people receiving free meals, so we cannot be sure that the number given is reliable. Secondly, most of the shelters with open access to the kitchen and the possibility to prepare food by the homeless themselves did not provide food products or offer ready hot meals. It could lead to a situation when homeless individuals do not have any ingredients to prepare a meal. Moreover, we did not receive data about the quality of the food.

According to the Municipal Social Welfare Centre, in Cracow kitchens, the provided meals were mainly one-dish $(n=5 ; 71.4 \%)$, especially soups $(n=4$; $57.1 \%)$. There were 2 places $(28.6 \%)$ serving twocourse meals. Four of these places $(57.1 \%)$ were also providing packed lunch for homeless individuals, and $1(14.3 \%)$ was preparing packages for holidays for them. Homeless people could also receive meals in 2 milk bars and 1 restaurant, thanks to the administrative decision (10). In our study, we did not receive clear information about the form of meals served in shelters, because the kind of meal often depended on the food available on a particular day. Koh et al. claim that, in half of the places preparing food for homeless people, the only hot meal provided was soup. It is clear that it cannot cover the total energy and nutrition needs. bezdomne miały możliwość przygotowania jedzenia samodzielnie. Z danych MOPS wynika, że w 2016 roku w Krakowie działało 7 kuchni przygotowujących gorące posiłki dla osób bezdomnych, starszych i biednych. Wszystkie instytucje łącznie przygotowywały około 1350 posiłków dziennie. W 2016 roku liczba wydanych posiłków wyniosła 328443 i była podobna jak w latach 2013-2015. Liczba osób korzystających $z$ tej pomocy w latach 2013-2015 wynosiła około 4000 rocznie (4). Z przedstawionych powyżej danych wynika, że liczba wydawanych posiłków przekracza szacowaną liczbę osób bezdomnych w Krakowie. Co więcej, liczba osób korzystających z darmowych posiłków jest wyższa niż oszacowana liczba bezdomnych w Krakowie, co sugeruje, że osoby biedne i starsze, niebędące osobami bezdomnymi, również korzystają z tej formy pomocy (4). W związku z powyższym, dostępność i liczba posiłków dla bezdomnych w Krakowie wydaje się być zadowalająca. Uzyskane dane trudno jednak ocenić jednoznacznie. Po pierwsze, nie ma dostępu do informacji na temat metod zastosowanych do policzenia osób korzystających z darmowych posiłków, więc nie ma pewności, czy podana liczba jest wiarygodna. Ponadto, większość schronisk z wolnym dostępem do kuchni i możliwością przygotowywania jedzenia nie zapewniała potrzebnych produktów. Mogło to prowadzić do sytuacji, gdy bezdomni nie mieli z czego przygotować posiłku. Nie uzyskaliśmy także danych o jakości żywności.

Według MOPS w krakowskich kuchniach podawano najczęściej posiłki jednodaniowe $(n=5 ; 71,4 \%)$, zwłaszcza zupy $(\mathrm{n}=4 ; 57,1 \%)$. W dwóch miejscach $(28,6 \%)$ serwowano dwudaniowy obiad. Cztery kuchnie $(57,1 \%)$ wydawały także paczki z jedzeniem dla bezdomnych, a w jednej (14,3\%) przygotowywano dla nich paczki na święta. Bezdomni mogli także korzystać z posiłków w 2 barach mlecznych i jednej restauracji na podstawie decyzji administracyjnej (10). W naszym badaniu nie uzyskaliśmy jednoznacznych informacji co do formy wydawanych posiłków w schroniskach, gdyż często rodzaj posiłku zależał od dostępnej w danym dniu żywności. Koh $i$ wsp. stwierdzają, iż w połowie miejsc przygotowujących jedzenie dla osób bezdomnych jedynym ciepłym posiłkiem była zupa. Oczywiste jest, że nie może to pokryć całkowitego zapotrzebowania organizmu na energię i składniki odżywcze. Co więcej bezdomni są populacją szczególnie narażoną na niedożywienie, z powodu alkoholizmu, zażywania narkotyków oraz chorób fizycznych i psychicznych (11). Nieodpowiednia dieta jest szkodliwa dla ich zdrowia, może między innymi zaburzyć proces gojenia ran (12).

Powszechnie wiadomo, iż ryzyko infekcji bakteryjnej i pasożytniczej wzrasta bez odpowiedniej higieny. Leibler $i$ wsp. nadmieniają, że dostęp do sanitaria- 
Moreover, the homeless are a population particularly vulnerable to malnutrition, because of alcoholism, drug use, physical and mental illnesses (11). Inappropriate diet is bad for their health, it may, inter alia, disturb the process of wound healing (12).

It is common knowledge that the risk of bacterial and parasitic infections increases without proper hygiene. Leibler et al. mention that access to sanitation facilities may also positively influence mental health. One of the social stigma factors is the appearance of the homeless and access to sanitation facilities increases the chance to find a job and transition out of homelessness (13). The previously mentioned Charter of Homeless Rights includes a declaration of access to toilets and showers for the homeless in order to maintain hygiene for the sake of health and dignity (14). According to the data from surveys, homeless people staying in institutions in Cracow (except one) have the opportunity to take a shower every day. They also have access to sanitary articles. However, the number of shower facilities in the majority of the shelters is inadequate with reference to the number of people staying there, which may hinder maintaining proper hygiene. In Cracow, there is only one public bath with five showers (condition as of July 2018). However, women can only use it two days a week (5 hours in total), while it is four days a week for men (17 hours in total). According to the data from the "Dzieło Pomocy św. Ojca Pio" foundation, every month, the homeless take about 500 showers there. Once a week, they can use the services of a hairdresser. Also, four washer-dryers are available (15). It is worth noticing that the public bath offers fewer showers per month than half the number of the homeless (500 showers vs 1,056 homeless people) $(4,15)$. Taking into account only this place, a single homeless person can take a shower only once in two months, which is insufficient considering the social standards in force when it comes to hygiene. Additionally, according to the data we received as streetworkers, people under the influence of alcohol cannot enter the area where the previously mentioned public bath is located.

Homelessness and health problems often coexistand affect each other. On one hand, a bad health condition and disability were the fifth most frequent reason for homelessness in Poland in 2017 and were responsible for 4,766 of its cases (13.2\%) (5). On the other hand, homelessness causes new diseases and worsens existing ones. As a result of a bad health condition, homeless people are more likely to benefit from medical care. Fazel et al. show that the homeless are more often admitted to hospital and their stay lasts longer (at least 2 days longer in severe cases) than in the general population (2). Bharel et al. mention that the homeless are more often admitted to the Emergency Room, i.e. tów może pozytywnie wpływać również na zdrowie psychiczne. Jednym z powodów stygmatyzacji społecznej jest wygląd bezdomnego, a dostęp do sanitariatów zwiększa szansę na znalezienie pracy i wyjście z bezdomności (13). Wspomniana wcześniej Karta Praw Bezdomnych zawiera deklarację dostępności do toalet i pryszniców celem utrzymania higieny dla godności człowieka (14). $Z$ danych uzyskanych przez nas w sondażu wynika, iż osoby bezdomne przebywające w placówkach prowadzonych na terenie Krakowa (z wyjątkiem jednej) mają możliwość korzystania z pryszniców codziennie. Mają też zapewniony dostęp do artykułów higienicznych. Jednak liczba pryszniców $\mathrm{w}$ większości schronisk jest nieproporcjonalna w stosunku do liczby przebywających tam osób, co może utrudniać utrzymywanie prawidłowego stanu higieny. W Krakowie dostępna jest tylko jedna publiczna łaźnia wyposażona w 5 pryszniców (stan na czerwiec 2018). Jednak kobiety mogą korzystać z niej tylko przez dwa dni w tygodniu (w sumie 5 godzin), a mężczyźni cztery dni (w sumie 17 godzin). Z danych Fundacji „Dzieło Pomocy św. Ojca Pio” wynika, iż co miesiąc bezdomni biorą około 500 pryszniców. Raz w tygodniu mogą skorzystać z usług fryzjera. Do dyspozycji mają 4 pralko- suszarki (15). Warto podkreślić, że liczba pryszniców oferowanych przez łaźnię publiczną jest o ponad połowę mniejsza, niż szacowana liczba osób bezdomnych (500 pryszniców vs. 1056 osób) (4, 15). Uwzględniając tylko to miejsce, każdy bezdomny mógłby się wykąpać tylko raz na dwa miesiące, co jest niewystarczające, zważywszy na obecne standardy społeczne dotyczące higieny. Dodatkowo z danych uzyskanych przez nas jako „streetworkerów” wynika, że osoby pod wpływem alkoholu nie mogą wejść na teren, na którym znajduje się wspomniana łaźnia.

Bezdomność i problemy zdrowotne często współistnieją ze sobą i wpływają na siebie. $Z$ jednej strony, zły stan zdrowia i niepełnosprawność były piątą $\mathrm{z}$ najczęstszych przyczyn bezdomności w Polsce w 2017 i były odpowiedzialne za jej 4766 przypadków (13.2\%) (5). Z drugiej strony, bezdomność powoduje wystąpienie nowych chorób i pogorszenie przebiegu już istniejących. Ze względu na słabą kondycję zdrowotną, bezdomni z większym prawdopodobieństwem korzystają z usług medycznych. Fazel $i$ wsp., wykazują, że bezdomni są częściej przyjmowani do szpitala, a ich pobyty są dłuższe (o co najmniej 2 dni w ostrych przypadkach) niż w populacji ogólnej (2). Bharel $i$ wsp. zaznaczają, iż osoby bezdomne częściej trafiają także do Szpitalnego Oddziału Ratunkowego- średnio cztery razy w roku (16). Jednak w sytuacjach mniej zagrażających życiu, osoby bezdomne mają ograniczony dostęp do opieki medycznej z powodu braku ubezpieczenia zdrowotnego. Stychlerz zaznacza, iż bezdomni objęci programem wychodzenia z bezdomności mieli 
4 times a year, on average (16). However, in less lifethreatening cases, the homeless have limited access to medical care due to the absence of health insurance. Stychlerz signalizes that homeless people included in the programme of recovery from homelessness had obligatory health insurance. Nevertheless, people not included in the programme had no insurance. They can apply for borough decision (proper to the place of residence) confirming the right to health benefits funded by public resources. The decision is based on community interview and the amount of income. Also, a homeless person must submit documents confirming Polish citizenship and residence in the territory of Poland (17). The last criterion could be a problem because homeless individuals often do not have such a document due to loss or theft. As a result, the majority of homeless people in Poland remain without medical care except for life-threatening conditions.

Data from the Municipal Social Welfare Centre in Cracow state that the percentage of ill and chronically ill people among the homeless in the years 2011-2016 was stabilized at the level of $64-68 \%$; however, in 2016 , this number increased and reached $77 \%$ (30\% for ill and 47\% for chronically ill) (4). Another problem among homeless people is disability. Almost 46\% of homeless people living in Cracow in 2016 were disabled. Similarly, this percentage increased since 2015 , when it amounted to $34.1 \%$ (and was stable since 2013) (4). This seems to be important in the discussion about providing medical help in places offering such help for the homeless in Cracow. Healthcare provided in the places surveyed is differentiated and regrettably insufficient. In the majority of the shelters surveyed, an ill person can be admitted under the condition that they are self-sufficient, however, the exact definition of this 'self-sufficiency' remains unclear. There are also no standards in force on the proceeding in the event of a person's condition getting worse and when he/ she requires specialist care in places without medical staff. In the majority of shelters, homeless individuals have the possibility to get medication if a doctor had prescribed it and they cannot afford it, and that creates the opportunity to treat residents of Cracow's shelters.

Medical help is also provided outside of shelters. As for medical care in Cracow, there is only one place (Clinic for Homeless and Poor People) run by "Doctors of Hope" helping homeless individuals (4). Medical services are provided regardless of health insurance by doctors, nurses, and trained volunteers. Only in 2016, there were 15956 interventions including consultations, small procedures like prescribing medicaments and putting on dressings. Another piece of evidence that the currently available medical care for homeless individuals in Cracow is inadequate is the activity of the newly created "Przystań Medyczna" obowiązkowe ubezpieczenie zdrowotne. Niemniej jednak, osoby niezakwalifikowane do podobnego programu nie miały obowiązkowego ubezpieczenia. Mogą one starać się o decyzję gminy (właściwej ze względu na miejsce zamieszkania) potwierdzającą prawo do świadczeń zdrowotnych ze środków publicznych. Decyzja taka wydawana jest na podstawie wywiadu środowiskowego i wielkości dochodu. Osoba bezdomna musi także dostarczyć dokumenty potwierdzające obywatelstwo polskie i zamieszkanie na terytorium Polski (17). Ostatnie kryterium może stanowić problem, ponieważ bezdomni często nie mają dokumentów z powodu zgubienia ich lub kradzieży. W związku z tym większość bezdomnych w Polsce pozostaje bez opieki medycznej poza stanami zagrożenia życia.

$Z$ danych krakowskiego MOPS wynika, że udział procentowy osób chorych i chorych przewlekle wśród bezdomnych w latach 2011-2016 był ustabilizowany na poziomie 64-68\%, jednak w 2016 liczba ta wzrosła i wyniosła $77 \%$ (30\% chorych i $47 \%$ chorych przewlekle) (4). Wśród osób bezdomnych częstym zjawiskiem jest również niepełnosprawność. Prawie $46 \%$ bezdomnych żyjących w Krakowie w 2016 roku stanowily osoby niepełnosprawne. Ponownie, liczba ta wzrosła od 2015 roku, kiedy to wynosiła 34,1\% (i była ustabilizowana na tym poziomie od 2013) (4). Fakt ten wydaje się być istotny w dyskusji na temat dostępności pomocy medycznej w placówkach pomagającym osobom bezdomnym w Krakowie. Opieka zdrowotna zapewniania w ankietowanych przez nas placówkach jest zróżnicowana i niestety zwykle niewystarczająca. W większości ankietowanych przez nas placówek chore osoby bezdomne były przyjmowane pod warunkiem „samoobsługi”, czego właściwe znaczenie pozostaje niejasne. Nie ma również ustalonych standardów postępowania w przypadkach pogorszenia stanu zdrowia, gdy chory wymaga opieki specjalistycznej w instytucjach, w których były braki personelu medycznego. W większości schronisk bezdomni mogli otrzymać leki, jeśli zostały przepisane przez lekarza, a sami nie mieli na nie środków, co umożliwiało leczenie podopiecznych krakowskich placówek.

Pomoc medyczna jest świadczona osobom bezdomnym także poza schroniskami. W Krakowie istnieje tylko jedna przychodnia (Przychodnia Lekarska dla Ludzi Bezdomnych i Ubogich) prowadzona przez Stowarzyszenie „Lekarze Nadziei”, zapewniająca pomoc osobom bezdomnym (4). Usługi medyczne są świadczone przez tę instytucję niezależnie od posiadania ubezpieczenia zdrowotnego, przez lekarzy, pielęgniarki i wyszkolonych wolontariuszy. Tylko w 2016 roku wykonano 15956 interwencji, na które składały się konsultacje lekarskie, małe zabiegi pielęgniarskie oraz wydawanie leków i materiałów opatrunkowych. Kolejnym dowodem na to, że obecna opieka zdrowot- 
foundation. The foundation has started its activity in November 2017 and since then has been providing medical care for homeless people during designated hours, twice a week, in Planty Park in Cracow. Help is provided by volunteer physicians and medical students. It is another important way of helping as there are no organizations providing medical help in the dwellings of the homeless. Also, this way, the activity of the foundation is aimed at individuals who cannot be found in the places surveyed.

\section{SUMMARY}

The socio-epidemiological situation of homeless people in Cracow is differentiated. Institutions providing overnight stay do not have enough places to accommodate all the homeless living in the city. However, the number of meals seems to cover the needs of homeless people concerning food, even if not every shelter provides meals for the residents. Kitchens which provide meals for people in need every day help shelters in that case. The possibility to maintain hygiene in the places surveyed also varies and is usually insufficient because the number of showers is unsatisfactory considering the number of residents. Additionally, access to basic medical help in institutions helping homeless people varies. In some of the shelters, medical help is provided by a physician, in the other ones by trained staff. Medical care is also provided by the Clinic run by "Doctors of Hope" and the "Przystań Medyczna" foundation which helps individuals who do not live in shelters or spikes. The creation of the Homeless Rights Card can prompt significant changes in the areas mentioned. All organizations helping homeless people should broaden the scope of help provided, especially as regards medical help.

\section{REFERENCES}

1. Harding J, Irving A, Whowell M. Homelessness, Pathways to Exclusion and Opportunities for Intervention. Arts and Social Sciences Academic Press 2011;2022:56-59.

2. Fazel S, Geddes JR, Kushel M. The health of homeless people in high-income countries: descriptive epidemiology, health consequences, and clinical and policy recommendations Lancet 2014;384:1529-40.

3. Ustawa z dnia 12 marca 2004 r. o pomocy społecznej. Dział I Przepisy ogólne. Rozdział 1 Zasady ogólne i zakres podmiotowy ustawy, Art. 6. (Dz.U. 2004 Nr 64 poz. 593)

4. Miejski Ośrodek Pomocy Społecznej. Ocena zasobów pomocy społecznej w Krakowie za rok 2015, Kraków 2016. https://www.bip.krakow.pl/zalaczniki/dokumenty/n/179096/karta [accessed 02.10.2018] na dostępna dla bezdomnych jest niewystarczająca, jest działalność nowopowstałej Fundacji „Przystań Medyczna". Zaczęła ona swą działalność w listopadzie 2017 i od tamtej pory zapewnia pomoc medyczną dla bezdomnych w wyznaczonych godzinach, dwa razy w tygodniu na terenie krakowskich plant. Pomocy udzielają lekarze-wolontariusze i studenci medycyny. To kolejny ważny sposób niesienia pomocy w przypadku braku wystarczającej opieki medycznej w miejscach pobytu bezdomnych. Także w ten sposób działalność Fundacji jest skierowana do osób bezdomnych, którzy z różnych przyczyn nie przebywają w ankietowanych placówkach.

\section{PODSUMOWANIE}

Sytuacja socjalno-epidemiologiczna osób bezdomnych w Krakowie jest zróżnicowana. Instytucje zapewniające nocleg nie dysponują wystarczającą liczbą miejsc w stosunku do liczby bezdomnych przebywających na terenie miasta. Natomiast liczba wydawanych posiłków wydaje się w pełni pokrywać zapotrzebowanie osób bezdomnych na wyżywienie, mimo iż nie wszystkie schroniska zapewniają posiłki osobom w nich przebywających. $\mathrm{Z}$ pomocą schroniskom przychodzą kuchnie, które wydają codziennie posiłki i tym samym zapewniają wyżywienie bezdomnym. Możliwość zapewnienia higieny w ankietowanych placówkach również jest niejednakowa i zwykle niedostateczna, gdyż liczba pryszniców w placówkach jest niewystarczająca w stosunku do liczby pensjonariuszy. Podobnie dostęp do podstawowej opieki medycznej $\mathrm{w}$ instytucjach pomagających osobom bezdomnym jest zróżnicowany. W niektórych schroniskach opiekę medyczną zapewniają lekarze, w innych przeszkolony personel. Pomoc medyczną dodatkowo zapewniają przychodnia Stowarzyszenia Lekarzy Nadziei oraz Fundacja Przystań Medyczna, która świadczy pomoc osobom bezdomnym niezamieszkującym schronisk i noclegowni. Stworzenie Karty Praw Bezdomnych może znacząco wpłynąć na zmiany we wskazanych obszarach. Wszystkie organizacje pomagające osobom bezdomnych powinny zwiększać zakres świadczonej pomocy, szczególnie pomocy medycznej.

5. Ministerstwo Rodziny, Pracy i Polityki Społecznej, Departament Pomocy i Integracji Społecznej. Sprawozdanie $\mathrm{z}$ realizacji działań na rzecz ludzi bezdomnych $\mathrm{w}$ województwach w roku 2016 oraz wyniki Ogólnopolskiego badania liczby osób bezdomnych (8/9 luty 2017). Warszawa, listopad 2017. https://archiwum.mpips.gov. $\mathrm{pl} /$ pomoc-spoleczna/bezdomnosc/materialy-informacyjne-na-temat-bezdomnosci/ [accessed 02.10.2018]

6. Second Overview of Housing Exclusion in Europe 2017. The Foundation Abbé Pierre - FEANTSA, 2017. 
https://www.feantsa.org/download/gb_housing-exclusion-report_complete_20178613899107250251219. pdf [accessed 04.10.2018]

7. Romaszko J, Kuchta R, Opalach C, et al.. Socioeconomic characteristics, health risk factors and alcohol consumption among the homeless in North-Eastern part of Poland Cent Eur J Public Health 2017;25(1):29-34.

8. Biuro Prewencji Komendy Głównej Policji Wydział Prewencji Informacja dotycząca zgonów osób z powodu wychłodzenia organizmu zaistniałych na terenie Polski, zarejestrowanych w systemie KSIP http://statystyka.policja.pl/st/wybrane-statystyki/zgony-z-powodu-wychlodz/50881,Zgony-z-powodu-wychlodzenia-organizmu.html?fbclid=IwAR2KsHbcgE9a8VNuIcykKJsPQE7NF5rY0j9QVBf6zdm5_1sDXnE6tqVx7pU [accessed 02.10.2018]

9. Karta Praw Osób doświadczających bezdomności https:// www.rpo.gov.pl/sites/default/files/Karta\%20Praw $\% 20$ Os\%C3\%B3b\%20do\%C5\%9Bwiadczaj\%C4\%85 cych $\% 20$ bezdomno $\%$ C5\%9Bci.pdf?fbclid=IwAR0LUoB0iK8lprulXthqFnM9Q6WZX2jVedU-LwVJzrmEdP8MartyiWwWLy0 [accessed 02.10.2018]

10. Miejski Ośrodek Pomocy Społecznej w Krakowie. Pomoc dla Osób Bezdomnych. https://mops.krakow.pl/ ogolne/214654,1934,komunikat,pomoc_dla_osob_bezdomnych.html [accessed 02.10.2018]

11. Koh KA, Bharel M, Henderson DC. Nutrition for homeless populations: shelters and soup kitchens as opportunities for intervention. Public Health Nutr 2016;19:1312-14.

12. Kłęk S. Rola leczenia żywieniowego w procesie leczenia ran Leczenie Ran, 2013;10(4): 95-9.
13. Leibler JH, Nguyen DD, León C, et al. Personal Hygiene Practices among Urban Homeless Persons in Boston, MA. Int J Environ Res Public Health 2017;14(8):928.

14. http://www.eapn.org.pl/wp-content/uploads/2018/02/ miejska-karta-praw-osob-bezdomnych.pdf

15. Dzieło Pomocy św. Ojca Pio. Pomoc doraźna. Pierwsza pomoc, gdy zabrakło domu. http://dzielopomocy.pl/jak-pracujemy/pomoc-dorazna [accessed 02.10.2018]

16. Bharel M, Lin WC, Zhang J, et al. Health care utilization patterns of homeless individuals in Boston: preparing for Medicaid expansion under the Affordable Care Act. Am J Public Health 2013;103(2):S311-7.

17. Stychlerz A. Zasady udzielania pomocy lekarskiej osobom bezdomnym. Forum Medycyny Rodzinnej 2009;3(1):77-9.

Received: 25.10.2018

Accepted for publication: 4.04.2019

Otrzymano: 25.10.2018

Zaakceptowano do publikacji: 4.04.2019

\section{Address for correspondence: \\ Adres do korespondencji:}

Katarzyna Talaga-Ćwiertnia

Department of Mycology, Chair of Microbiology

Faculty of Medicine,

Jagiellonian University Medical College

ul. Czysta 18, 31-121 Kraków

Tel. 12/ 6332567 ext. 231

E-mail: katarzyna.talaga@uj.edu.pl 